\title{
Characteristics and sources of lead pollution after phasing out leaded gasoline in Beijing
}

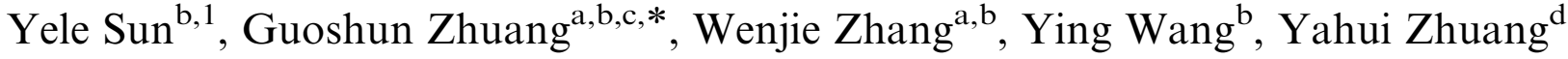 \\ ${ }^{a}$ Center for Atmospheric Chemistry Study, Department of Environmental Science and Engineering, Fudan University, \\ Shanghai 200433, China \\ ${ }^{\mathrm{b}}$ Center for Atmospheric Environmental Study, Department of Chemistry, Beijing Normal University, Beijing 100875, China \\ ${ }^{\mathrm{c}} \mathrm{NZC} / \mathrm{LAPC}$, Institute of Atmospheric Physics, Chinese Academy of Science, Beijing 100029, China \\ ${ }^{\mathrm{d}}$ Research Center for Eco-Environmental Sciences, Chinese Academy of Science, Beijing 100085, China
}

Received 19 August 2005; accepted 21 December 2005

\begin{abstract}
A 5-year long-term programme of $\mathrm{Pb}$-monitoring from 2000 to 2004 was carried out at three representative urban sites (a traffic, an industrial, and a residential site), and a suburban site to evaluate the pollution level of Pb in Beijing. For comparison, aerosol samples were also collected in four other cities, Shanghai, Qingdao, Duolun, and Yulin in $\mathrm{China}$. $\mathrm{Pb}$ pollution in Beijing has been very serious when compared with other sites over the world, as the concentration of $\mathrm{Pb}$ in Beijing remained as high as $\sim 100-300 \mathrm{ng} \mathrm{m}^{-3}$ in fine particles $\left(\mathrm{PM}_{2.5}\right)$. Significant spatial variation of $\mathrm{Pb}$ in summer with the highest concentration at the industrial site was observed, while relatively even spatial variation was found in winter in urban area, although much heavier in the urban area than at suburban site. Strong seasonal variation of $\sim 2-3$ times higher $\mathrm{Pb}$ concentration in winter than that in summer was found. $\mathrm{Pb}$ exhibited a unimodal size distribution with most of it in fine fraction. $\mathrm{Pb}$ in fine particles was enriched by a factor of $200-1600$ relative to its abundance in crust. Besides industry emission, motor vehicle emission, and coal burning, long-range transported dust from outside Beijing and the re-suspended soil containing the deposition of those from previously emitted leaded gasoline could be the important sources of $\mathrm{Pb}$ in Beijing.
\end{abstract}

(C) 2006 Elsevier Ltd. All rights reserved.

Keywords: Lead; Urban pollution; Atmospheric pollution; Sources; China; Beijing

\footnotetext{
*Corresponding author. Department of Environmental Science and Engineering, Center for Atmospheric Chemistry Study, Fudan University, Shanghai 200433, China.

Tel.: + 8621 55664579; fax: + 861082902844 .

E-mail addresses: gzhuang@bnu.edu.cn, gszhuang@126.com (G. Zhuang).

${ }^{1}$ Now at Centre for Atmosphere Watch and Services, Chinese Academy of Meteorological Sciences, China Meteorological Administration, Beijing, China.
}

\section{Introduction}

Lead, the only metal listed in the National Ambient Air Quality Standard of China, has attracted public attention for several decades because of its adverse effects on human health, especially on children's growth and intelligence. It was reported (Chen et al., 2003) that the blood lead level of $35.7 \%$ children at Beijing in 2001 exceeded the $\mathrm{Pb}$ poisoning standard $\left(100 \mu \mathrm{g} \mathrm{L}^{-1}\right)$ regulated by 
the World Health Organization (Centers for Disease Control and Prevention, 1991). Pb in the atmosphere can be deposited in urban soils (Wong and $\mathrm{Li}, 2004$ ), and may then be re-suspended to re-enter the atmosphere (Young et al., 2002). This could increase human exposure to $\mathrm{Pb}$ and cause long-term potential health effects (Nriagu and Pacyna, 1988). Thus, monitoring $\mathrm{Pb}$ pollution has been one of the major tasks in controlling air pollution worldwide.

The global emission of trace elements increased significantly due to anthropogenic activities before 1970s (Nriagu, 1979). Among these trace elements, the increase of $\mathrm{Pb}$ is largely attributed to the vehicles and roadside emissions (Nriagu, 1989). Pb contributes more than $20 \%$ of the total mass of those fine particles emitted from burning of leaded gasoline, of which approximately $75 \%$ is emitted directly to the atmosphere (Pacyna, 1998). Tetraethyl $\mathrm{Pb}$ was first introduced as anti-knocking gasoline additives in the $1920 \mathrm{~s}$, and $\mathrm{Pb}$ concentration in the atmosphere continually increased from that time, although it has declined in the last few decades. Until 1970s, when the toxicity of $\mathrm{Pb}$ was realized, the airborne $\mathrm{Pb}$ concentrations in USA, Japan, and many countries in Europe first began to decrease due to the phase-out of leaded gasoline. In California $\mathrm{Pb}$ concentration declined from $\sim 3000 \mathrm{ng} \mathrm{m}^{-3}$ in the early 1970s (Miller et al., 1972) to less than $10 \mathrm{ng} \mathrm{m}^{-3}$ (Chow et al., 1996) in 1990s. In China, the use of leaded gasoline was banned first in Beijing in 1997, and then in Shanghai, Guangzhou, Tianjin and other big cities. Wang et al. (2003) evaluated the phase-out of leaded gasoline in Tianjin using isotope techniques $\left({ }^{206} \mathrm{~Pb} /{ }^{207} \mathrm{~Pb}\right)$. They found that $\mathrm{Pb}$ concentration in 1994-2001 decreased a little, while $\mathrm{Pb}$ isotope ratio $\left({ }^{206} \mathrm{~Pb} /{ }^{207} \mathrm{~Pb}\right)$ increased gradually. The results indicated that the contributions from vehicles emission decreased, whereas those from other sources likely increased. The results based on the individual particle analysis with the pattern recognition technique combined with micro-PIXE spectrum indicated that the low level $\mathrm{Pb}$ concentration in most unleaded gasoline particles was still the important input of $\mathrm{Pb}$ to the atmosphere in Shanghai. The other four major sources of lead were cement industry, coal combustion, oil combustion, and metallurgic industry (Wang et al., 2000). However, studies on $\mathrm{Pb}$ pollution at Beijing are rather limited. $\mathrm{Pb}$ concentration in 1999 decreased clearly compared with that in 1987 (Zhang et al., 2000). He et al. (2001) reported the annual $\mathrm{Pb}$ average concentration of $0.30 \mu \mathrm{g} \mathrm{m}^{-3}$ in $1999-2000$ in Beijing and those possible sources, such as reentrained dust, transport from areas outside Beijing, vehicles using leaded fuel coming from other places into Beijing, non-automobile sources, were speculated. Beijing remains high concentration of $\mathrm{Pb}$ after the phase-out of leaded gasoline and, however, the sources of $\mathrm{Pb}$ are poorly understood. The question of the heavy $\mathrm{Pb}$ pollution and its sources must be addressed urgently. In this study, we report a longterm monitoring of $\mathrm{Pb}$ from 2000 to 2004 in Beijing and try to answer the question mentioned above.

\section{Experimental}

\subsection{Sampling}

Aerosol samples of total suspended particles (TSP), with aerodynamic diameters of less than $100 \mu \mathrm{m}, \mathrm{PM}_{10}$ (particles with aerodynamic diameters of less than $10 \mu \mathrm{m}$ ), and $\mathrm{PM}_{2.5}$ (particles with aerodynamic diameters of less than $2.5 \mu \mathrm{m}$ ) were collected in different seasons from 2000 to 2004 at five cities of China (see Fig. 1), i.e. Beijing, Shanghai, Qingdao, Yulin, and Duolun. The detailed descriptions of sampling sites are summarized in Table 1.

TSP, $\mathrm{PM}_{10}$, and $\mathrm{PM}_{2.5}$ aerosol samples were all collected on Whatman ${ }^{\circledR} 41$ filters (Whatman Inc.,

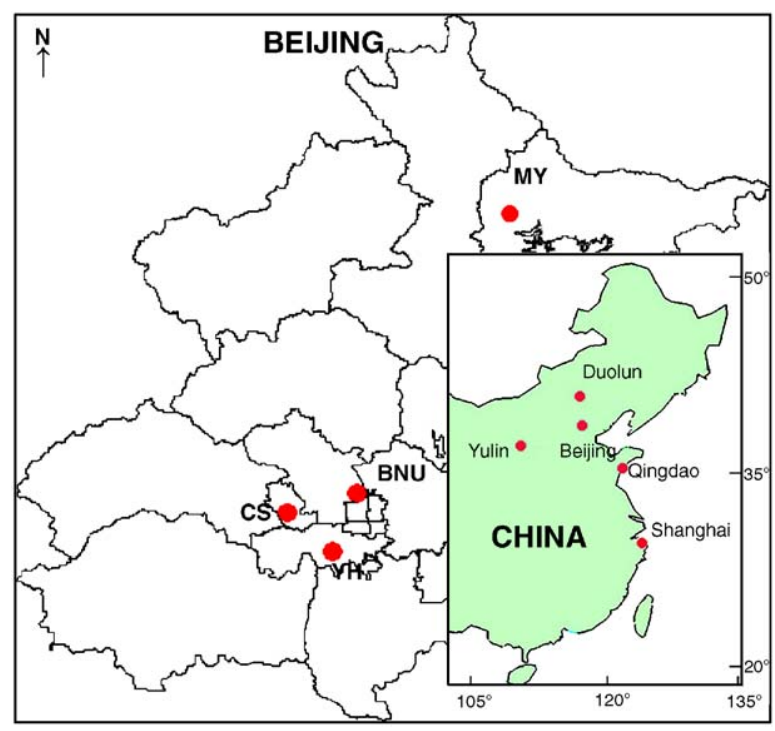

Fig. 1. Geographical locations of sampling sites in this study (BNU: Beijing Normal University; CS: Capital Steel Company; YH: Yihai Garden; MY: Miyun Hydrologic Station). 
Table 1

A summary of sampling information and relevant environmental parameters in five cities of China

\begin{tabular}{|c|c|c|c|c|c|c|c|}
\hline City & Environment & Description & Year & Season & Annual $P^{\mathrm{a}}$ & Mean $T^{\mathrm{b}}$ & Population $^{\mathrm{c}}$ \\
\hline Beijing & & & & & 338.9 & 12.9 & 1128 \\
\hline \multirow[t]{7}{*}{$\mathrm{BNU}$} & Traffic & $\begin{array}{l}\text { Twelve-story building of science } \\
\text { and technology }(\sim 40 \mathrm{~m}) \text { in Beijing } \\
\text { Normal University between the } 2 \mathrm{nd} \\
\text { and } 3 \mathrm{rd} \text { ring roads }\end{array}$ & 2001 & Winter & & & \\
\hline & & & 2002 & Spring & & & \\
\hline & & & 2002 & Summer & & & \\
\hline & & & 2002 & Winter & & & \\
\hline & & & 2003 & Spring & & & \\
\hline & & & 2003 & Autumn & & & \\
\hline & & & 2004 & Spring & & & \\
\hline \multirow[t]{2}{*}{$\mathrm{CS}$} & Industrial & $\begin{array}{l}\text { A building }(\sim 4 \mathrm{~m}) \text { close to Capital } \\
\text { Steel Company }\end{array}$ & 2002 & Summer & & & \\
\hline & & & 2002 & Winter & & & \\
\hline \multirow[t]{2}{*}{ YH } & Residential & $\begin{array}{l}\text { A residential building }(\sim 40 \mathrm{~m}) \text { in } \\
\text { Yihai Garden near the South } 4 \text { th } \\
\text { Ring Road }\end{array}$ & 2002 & Summer & & & \\
\hline & & & 2002 & Winter & & & \\
\hline \multirow[t]{3}{*}{ MY } & Suburban & $\begin{array}{l}\text { A building }(\sim 4 \mathrm{~m}) \text { in Miyun } \\
\text { Hydrologic Station }\end{array}$ & 2003 & Spring & & & \\
\hline & & & 2003 & Autumn & & & \\
\hline & & & 2004 & Spring & & & \\
\hline \multirow[t]{2}{*}{ Shanghai } & Suburban & $\begin{array}{l}\text { Five-story teaching building } \\
(\sim 15 \mathrm{~m}) \text { in Fudan University }\end{array}$ & 2003 & Autumn & 1200 & 16.0 & 1674 \\
\hline & & & 2004 & Spring & & & \\
\hline Qingdao & Coastal & $\begin{array}{l}\text { Three-story meteorological station } \\
(\sim 10 \mathrm{~m}) \text { on the top of Baguan hill in } \\
\text { the Ocean University of China }\end{array}$ & 2004 & Spring & 776 & 12.2 & 707 \\
\hline Yulin & Suburban & $\begin{array}{l}\text { Four-story building }(\sim 10 \mathrm{~m}) \text { in } \\
\text { Shaanxi Research Institute for Sand } \\
\text { Control }\end{array}$ & 2004 & Spring & 414 & 8.1 & 41 \\
\hline \multirow[t]{3}{*}{ Duolun } & Urban & $\begin{array}{l}\text { Four-story Teaching Building } \\
(\sim 10 \mathrm{~m}) \text { in the No. } 3 \text { Middle School }\end{array}$ & 2003 & Spring & 385 & 1.6 & 10 \\
\hline & & & 2003 & Autumn & & & \\
\hline & & & 2004 & Spring & & & \\
\hline
\end{tabular}

${ }^{\mathrm{a}} P=$ Precipitation $(\mathrm{mm})$.

${ }^{\mathrm{b}} T=$ Temperature $\left({ }^{\circ} \mathrm{C}\right)$.

${ }^{\mathrm{c}}$ Units in 10,000 .

Maidstone, UK) using medium-volume samplers manufactured by Beijing Geological InstrumentDickel Co., Ltd. (model: TSP/PM $10 / \mathrm{PM}_{2.5}-2$; flow rate: $77.59 \mathrm{~L} \mathrm{~min}^{-1}$ ). All those filters were weighed before and after sampling with an analytical balance (Sartorius 2004MP, reading precision $10 \mu \mathrm{g}$ ) after stabilizing in constant temperature $\left(20 \pm 5^{\circ} \mathrm{C}\right)$ and humidity $(40 \pm 2 \%)$. All the procedures were strictly quality-controlled to avoid any possible contamination of the samples. To study further the sources of
$\mathrm{Pb}$, soil samples were also collected at seven typical sites located in different geographical areas with various sources at Beijing: downtown areas of second ring road, of third ring road, of fourth ring road, a place near a gas station, a residential area, an industry area, and a construction area. For comparison, the soil samples were also collected at Duolun in Inner Mongolia, one of the sources of dust storm. The detailed information on soil sampling was given in Han et al. (2005). 
Sixteen sets of size-segregated samples were collected on the top of a two-floor building ( $\sim 6 \mathrm{~m}$ high) from August 2000 to March 2001 at the Institute of Atmospheric Physics, Chinese Academy of Science in Beijing using Battelle-type cascade impactors (the flow rates is approximately $1.25 \mathrm{~L} \mathrm{~m}^{-3}$ ), which has eight size-fractionated stages with the size range of $<0.25,0.25-0.5,0.5-1,1-2$, $2-4,4-8,8-16$ and $>16 \mu \mathrm{m}$ respectively. The $50 \%$ cut off diameters $\left(\mathrm{D}_{50}\right)$ of eight impactor stages were $0.12,0.25,0.50,1.0,2.0,4.0,8.0,16 \mu \mathrm{m}$ respectively. The sampling usually started at 8:00 a.m. and ended at 6:00 p.m., and then another sample was collected from 6:00 p.m. to 8:00 a.m. the next day.

\subsection{Chemical analysis}

The sample filters were digested at $170{ }^{\circ} \mathrm{C}$ for $4 \mathrm{~h}$ in high-pressure Teflon digestion vessel with $3 \mathrm{~mL}$ concentrated $\mathrm{HNO}_{3}, 1 \mathrm{~mL}$ concentrated $\mathrm{HCl}$, and $1 \mathrm{~mL}$ concentrated HF. After cooling, the solutions were dried, and then diluted to $10 \mathrm{~mL}$ with distilled-deionized water. In total, 23 elements including $\mathrm{Pb}$ were determined by inductively coupled plasma atomic emission spectroscopy (ICP-AES, Model: ULTIMA, JOBIN-YVON Company, France). The detailed analytical procedures are given elsewhere (Zhuang et al., 2001, 2003). The soil samples were first sieved, only allowing particles with diameter smaller than $30 \mu \mathrm{m}$ to pass through, and then they were analyzed following the methods above.

\section{Results and discussion}

\subsection{Pb level in Beijing}

The concentrations of $\mathrm{Pb}$ at four sites in Beijing from 2001 to 2004 and at other cities in China from 2003 to 2004 are presented in Table 2. The quarterly and annual average of National Ambient Air Quality Standard for $\mathrm{Pb}$ is not to exceed 1.5 and

Table 2

Statistical summary of $\mathrm{Pb}$ concentrations $\left(\mathrm{ng} \mathrm{m}^{-3}\right)$ in five cities of China

\begin{tabular}{|c|c|c|c|c|c|c|c|c|c|c|c|c|c|}
\hline \multirow[t]{2}{*}{ City } & \multirow[t]{2}{*}{ Sampling period } & \multicolumn{4}{|l|}{ TSP } & \multicolumn{4}{|l|}{$\mathrm{PM}_{10}$} & \multicolumn{4}{|l|}{$\mathrm{PM}_{2.5}$} \\
\hline & & Mean & SD & Range & $N$ & Mean & SD & Range & $N$ & Mean & SD & Range & $N$ \\
\hline \multicolumn{14}{|l|}{ Beijing } \\
\hline \multirow[t]{7}{*}{$\mathrm{BNU}$} & Win-01 & 235.8 & 231.1 & $9.8-813.1$ & 35 & 187.9 & 147.4 & $15.9-600.5$ & 32 & 206.0 & 193.9 & $33.3-760.1$ & 19 \\
\hline & Spr-02 & 236.9 & 176.5 & $8.4-850.8$ & 81 & 104.1 & 103.5 & $3.3-495.7$ & 31 & 124.7 & 124.6 & $0.0-558.4$ & 43 \\
\hline & Sum-02 & 93.6 & 27.6 & $69.9-123.8$ & 3 & 112.5 & 86.6 & $5.2-268.0$ & 18 & 109.6 & 53.9 & $36.5-206.8$ & 19 \\
\hline & Win-02 & & & & & 365.2 & 365.9 & $68.7-1534.3$ & 19 & 310.9 & 328.0 & $44.6-1446.5$ & 20 \\
\hline & Spr-03 & 303.4 & 322.2 & $17.6-1348.9$ & 28 & 233.5 & 206.2 & $12.0-907.0$ & 28 & 135.8 & 115.0 & $11.3-421.3$ & 20 \\
\hline & Aut-03 & 193.9 & 164.3 & $14.4-639.8$ & 20 & & & & & 186.2 & 202.6 & $8.9-943.1$ & 22 \\
\hline & Spr-04 & 307.0 & 262.0 & $9.3-990.8$ & 41 & & & & & 175.7 & 145.3 & $8.2-595.9$ & 50 \\
\hline \multirow[t]{2}{*}{$\mathrm{CS}$} & Sum-02 & & & & & 218.8 & 106.1 & $46.2-483.2$ & 22 & 198.2 & 95.5 & $51.0-467.1$ & 21 \\
\hline & Win-02 & & & & & 463.9 & 395.2 & $36.0-1524.0$ & 18 & 265.1 & 174.8 & $19.0-702.8$ & 20 \\
\hline \multirow[t]{2}{*}{ YH } & Sum-02 & & & & & 112.5 & 78.7 & $4.1-286.0$ & 21 & 101.9 & 48.0 & $15.5-196.5$ & 20 \\
\hline & Win-02 & & & & & 490.6 & 422.9 & $65.8-1735.9$ & 18 & 316.3 & 233.1 & $57.6-881.7$ & 20 \\
\hline \multirow[t]{3}{*}{ MY } & Spr-03 & & & & & 129.8 & 130.1 & $3.1-501.2$ & 31 & 70.2 & 58.8 & $0.0-199.3$ & 26 \\
\hline & Aut-03 & 139.7 & 135.1 & $0.4-442.6$ & 18 & & & & & 98.7 & 89.1 & $2.1-298.2$ & 20 \\
\hline & Spr-04 & 147.3 & 162.0 & $3.6-656.8$ & 47 & & & & & 195.0 & 186.2 & $7.1-629.4$ & 47 \\
\hline \multirow[t]{2}{*}{ Shanghai } & Aut-03 & 45.5 & 40.9 & $7.0-169.4$ & 19 & & & & & 39.3 & 31.4 & $1.8-141.5$ & 19 \\
\hline & Spr-04 & 176.1 & 145.5 & $38-546$ & 22 & & & & & 85.5 & 64.0 & $18.0-290.5$ & 32 \\
\hline Qingdao & Spr-04 & 156.3 & 144.8 & $13.4-650$ & 37 & & & & & 161.4 & 139.0 & $4.8-696.2$ & 43 \\
\hline Yulin & Spr-04 & 69.6 & 63.3 & $4.6-295.1$ & 44 & & & & & 43.4 & 44.1 & $2.5-226.3$ & 46 \\
\hline \multirow[t]{3}{*}{ Duolun } & Spr-03 & 43.3 & 28.0 & $7.5-117.7$ & 30 & & & & & & & & \\
\hline & Aut-03 & 27.9 & 23.8 & $1.4-90.3$ & 13 & & & & & 34.5 & 33.8 & $3.6-107.4$ & 13 \\
\hline & Spr-04 & 30.1 & 41.8 & $2.1-222.5$ & 33 & & & & & 28.6 & 32.2 & $4.8-149.6$ & 46 \\
\hline
\end{tabular}

Note $:$ Spr $=$ Spring, Sum $=$ Summer, Aut $=$ Autumn, and Win $=$ Winter . 
$1.0 \mu \mathrm{g} \mathrm{m}^{-3}$, respectively. Although the average concentrations of $\mathrm{Pb}$ at the urban site (BNU, CS, and $\mathrm{YH}$ ), and suburban site (MY) reported in this study were below the standard, it could be seen clearly that a considerable amount of $\mathrm{Pb}$ was found in the atmosphere of Beijing. The highest average concentration of $\mathrm{Pb}$ in the urban area in TSP, $\mathrm{PM}_{10}$, and $\mathrm{PM}_{2.5}$ in different season was 307.0, 490.6, and $316.3 \mathrm{ng} \mathrm{m}^{-3}$, respectively. Even if the lowest seasonal average concentration, it was high up to 93.6, 104.1, and $101.9 \mathrm{ng} \mathrm{m}^{-3}$ in TSP, $\mathrm{PM}_{10}$ and $\mathrm{PM}_{2.5}$, respectively. The highest average concentration of $\mathrm{Pb}$ at suburban site was $195.0 \mathrm{ng} \mathrm{m}^{-3}$ in $\mathrm{PM}_{2.5}$ in spring of 2004 and the lowest was $70.2 \mathrm{ng} \mathrm{m}^{-3}$ in spring of 2003. The results indicated that, though leaded gasoline has been banned in Beijing since 1997, $\mathrm{Pb}$ pollution is still very serious in Beijing, and it is much heavier in urban area than suburban area. As the number of motor vehicles in Beijing increased by $10-15 \%$ per year in the recent years and reached 2.2 million in the first half year of 2004, the motorization of the city has brought much more air pollutants, including $\mathrm{Pb}$, to the atmosphere. The atmospheric $\mathrm{Pb}$ concentrations in Beijing and other cities of China reported previously are shown in Table 3. The pollution level of $\mathrm{Pb}$ in Beijing in the early 1980 s was $\sim 90 \mathrm{ng} \mathrm{m}^{-3}$ (Winchester and $\mathrm{Bi}, 1984)$. As the rapid increase of motor vehicles, $\mathrm{Pb}$ concentration reached $\sim 200 \mathrm{ng} \mathrm{m}^{-3}$ in the late 1980s (Chen et al., 1994) and remained in a high level in the following few years. $\mathrm{Hu}$ and $\mathrm{Wu}$ (1999) investigated the $\mathrm{Pb}$ pollution level in four cities of China, i.e., Guangzhou, Wuhan, Lanzhou, and Chongqing, from 1995 to 1996, and found that the concentration of $\mathrm{Pb}$ in $\mathrm{PM}_{2.5}$ was as high as to $476.4 \mathrm{ng} \mathrm{m}^{-3}$ in Guangzhou and even to $635.9 \mathrm{ng} \mathrm{m}^{-3}$ in Lanzhou. Beijing first prohibited the use of leaded gasoline in July 1997. However, Pb concentration in the atmosphere has not decreased markedly since then. The annual average $\mathrm{Pb}$ concentration in $\mathrm{PM}_{2.5}$ at a residential site (Tsinghua University) and a downtown site (Chegongzhuang) in Beijing from 1999 to 2000 was 335 and $304 \mathrm{ng} \mathrm{m}^{-3}$, respectively (He et al., 2001), while it was 280 and $270 \mathrm{ng} \mathrm{m}^{-3}$ at a downtown site (Hainan Road) and a residential site (Tongji University), respectively, in Shanghai (Ye et al., 2003). Our 5year long-term programme of $\mathrm{Pb}$-monitoring from 2001 to 2004 showed that $\mathrm{Pb}$ in $\mathrm{PM}_{2.5}$ in Beijing maintained levels of $\sim 100-300 \mathrm{ng} \mathrm{m}^{-3}$. The highest average concentration of $\mathrm{Pb}$ was $316.3 \mathrm{ng} \mathrm{m}^{-3}$ at the residential site $(\mathrm{YH})$ in winter of 2002 and the lowest average concentration was $70.2 \mathrm{ng} \mathrm{m}^{-3}$ at the suburban site (MY) in spring of 2003. The results above indicated that $\mathrm{Pb}$ pollution remained a high level in the past few years even after phasing out of leaded gasoline in Beijing.

\subsection{Comparison with other sites in the world}

The concentrations of $\mathrm{Pb}$ in ambient suspended particulates at different cities around the world are listed in Table 3. When compared with those reported previously at other sites in Asia, America, and Europe, it was found clearly that the pollution level of $\mathrm{Pb}$ in Beijing was the heaviest among all of these cities reported. Similar studies carried out in other urban areas of Asia reported concentrations of only 76.86 and $91.62 \mathrm{ng} \mathrm{m}^{-3}$ at a traffic site (Hung Hom) and an industrial site (Kwun Tong), respectively, in Hong Kong (Ho et al., 2003), and $200 \mathrm{ng} \mathrm{m}^{-3}$ at Seoul in Korea (Mishra et al., 2004). The low $\mathrm{Pb}$ concentration of $34 \mathrm{ng} \mathrm{m}^{-3}$ in $\mathrm{PM}_{2.5}$, $36 \mathrm{ng} \mathrm{m}^{-3}$ in $\mathrm{PM}_{10}$, and $44 \mathrm{ng} \mathrm{m}^{-3}$ in TSP in the winter of 2000 were found at a traffic site in Taichung in Taiwan (Fang et al., 2002). Pb concentrations reported in most of the sites in Europe and America were distinctly lower than those in Beijing. Gao et al. (2002) reported the $\mathrm{Pb}$ concentration of only $4.9-7.9 \mathrm{ng} \mathrm{m}^{-3}$ in $\mathrm{PM}_{2.5}$ at three locations over New Jersey near New York from 1998 to 2000. The low $\mathrm{Pb}$ concentration of $\sim 6 \mathrm{ng} \mathrm{m}^{-3}$ in fine particles was observed in Helsinki in Finland from 1996 to 1997 (Pakkanen et al., 2001). Similar level of $\mathrm{Pb}$ ranging from $1-11 \mathrm{ng} \mathrm{m}^{-3}$ was also observed at ten sites in the central California in the early 1990s (Chow et al., 1996). It is clear from these comparisons that the atmosphere in Beijing is still heavily $\mathrm{Pb}$ polluted.

\subsection{Spatial variation of $\mathrm{Pb}$ in Beijing}

To better evaluate the pollution level of $\mathrm{Pb}$ in Beijing, $\mathrm{Pb}$ concentrations at four sites of Beijing (BNU, CS, YH, and MY) were compared with other four cities in China. $\mathrm{Pb}$ showed significant spatial variations in summer in Beijing (one-way ANOVA, $p<0.001$ at a significance level of 95\%). The average concentration of $\mathrm{Pb}$ in summer of 2002 was 218.8 and $198.2 \mathrm{ng} \mathrm{m}^{-3}$ in $\mathrm{PM}_{10}$ and $\mathrm{PM}_{2.5}$, respectively, at the industrial site, $\mathrm{CS}$, nearly double that at the other two sites, BNU and YH. The concentrations of chemical species at a specific location are strongly determined by the distances 
Table 3

The atmospheric $\mathrm{Pb}$ concentrations $\left(\mathrm{ng} \mathrm{m}^{-3}\right)$ in Beijing and other cities over the world

\begin{tabular}{|c|c|c|c|c|c|c|}
\hline Site & Period & Mean & Type & Instrument & Environment & Source \\
\hline \multicolumn{7}{|l|}{ 1. Asia (China) } \\
\hline \multicolumn{7}{|l|}{ Beijing } \\
\hline & July 1980 & 310 & $\mathrm{PM}_{2.0}$ & PIXE & Urban & Winchester and $\mathrm{Bi}(1984)$ \\
\hline & & 72 & $\mathrm{PM}_{>2.0}$ & & & \\
\hline & December 1980 & 90 & $\mathrm{PM}_{2.0}$ & & & \\
\hline & & 92 & $\mathrm{PM}_{>2.0}$ & & & \\
\hline Tiananmen & 30 April 1989-14 May 1990 & 210 & $\mathrm{PM}_{2.5}$ & $\mathrm{XRF}$ & Traffic & Chen et al. (1994) \\
\hline Chenggongzhuang & July 1999-September 2000 & 304 & $\mathrm{PM}_{2.5}$ & $\mathrm{XRF}$ & Urban & He et al. (2001) \\
\hline Tsinghua & & 335 & $\mathrm{PM}_{2.5}$ & & Subarban & \\
\hline Guangzhou & 1995-1996 & 476.4 & $\mathrm{PM}_{2.5}$ & $\mathrm{XRF}$ & Traffic & $\mathrm{Hu}$ and $\mathrm{Wu}(1999)$ \\
\hline Wuhan & & 310.4 & $\mathrm{PM}_{2.5}$ & & Urban & \\
\hline Lanzhou & & 635.9 & $\mathrm{PM}_{2.5}$ & & Urban & \\
\hline Chongqing & & 220.4 & $\mathrm{PM}_{2.5}$ & & Urban & \\
\hline \multicolumn{7}{|l|}{ Shanghai } \\
\hline Hainan Road & March 1999-March 2000 & 280 & $\mathrm{PM}_{2.5}$ & XRF & Urban & Ye et al. (2003) \\
\hline Tongji & & 270 & $\mathrm{PM}_{2.5}$ & $\mathrm{XRF}$ & Suburban & \\
\hline \multicolumn{7}{|l|}{ 2. Asia (Taiwan) } \\
\hline \multicolumn{7}{|l|}{ Taichung } \\
\hline \multirow[t]{3}{*}{$C C R T$} & 2 November-30 November 2000 & 34 & $\mathrm{PM}_{2.5}$ & AAS & Traffic & Fang et al. (2002) \\
\hline & & 36 & $\mathrm{PM}_{10}$ & & & \\
\hline & & 44 & TSP & & & \\
\hline \multicolumn{7}{|l|}{ 3. Asia (Hong Kong) } \\
\hline \multirow[t]{2}{*}{ Hung Hom } & November 2000-February 2001 & 76.86 & $\mathrm{PM}_{2.5}$ & ICP-MS & High traffic & Ho et al. (2002) \\
\hline & & 98.74 & $\mathrm{PM}_{10}$ & & & \\
\hline \multirow[t]{2}{*}{ Kwon Tong } & November 2000-February 2001 & 91.62 & $\mathrm{PM}_{2.5}$ & & Industrial & \\
\hline & & 100.5 & $\mathrm{PM}_{10}$ & & & \\
\hline \multicolumn{7}{|l|}{ 4. Asia (Korea) } \\
\hline \multirow[t]{2}{*}{ Seoul } & March-May 2001 & 120 & $\mathrm{PM}_{10}$ & ICP-AES & Urban & Kim et al. (2003) \\
\hline & 9-25 December 2002 & 200 & $\mathrm{PM}_{10}$ & ICP-AES & Urban & Mishra et al. (2004) \\
\hline Jeju & 9-25 December 2002 & 27.6 & $\mathrm{PM}_{10}$ & ICP-AES & Rural & Mishra et al. (2004) \\
\hline \multicolumn{7}{|l|}{ 5. North America (USA) } \\
\hline \multicolumn{7}{|l|}{ New York } \\
\hline Sandy Hook & January 1998-July 1999 & 4.9 & $\mathrm{PM}_{2.5}$ & ICP-MS & Coastal & Gao et al. (2002) \\
\hline Liberty Science Center & October 1998-January 2000 & 7.9 & $\mathrm{PM}_{2.5}$ & & Urban & \\
\hline New Brunswick & January 1998-December 1999 & 6.6 & $\mathrm{PM}_{2.5}$ & & Urban & \\
\hline Central California & 13 July-24 August 1999 & $1-11$ & $\mathrm{PM}_{2.5}$ & $\mathrm{XRF}$ & Total & Chow et al. (1996) \\
\hline \multicolumn{7}{|l|}{ 6. Europe (Finland) } \\
\hline \multirow[t]{4}{*}{ Helsinki } & October 1996-May 1997 & 5.8 & $\mathrm{PM}_{2.3}$ & PIXE & Urban & Pakkanen et al. (2001) \\
\hline & & 5.5 & $\mathrm{PM}_{2.3}$ & & Rural & \\
\hline & & 2.0 & $\mathrm{PM}_{2.3-15}$ & & Urban & \\
\hline & & 0.63 & $\mathrm{PM}_{2.3-15}$ & & Rural & \\
\hline
\end{tabular}

from the sources, which could reflect the emissions from those point sources. CS site is located at a place close to Capital Steel Plant, the largest emission source of those industrial pollutants. Thus the highest concentration of $\mathrm{Pb}$ at the industrial site, $\mathrm{CS}$, indicated that the industry emission could be an important source of $\mathrm{Pb}$ in Beijing. The spatial variation of $\mathrm{Pb}$ in winter in both $\mathrm{PM}_{10}$ and $\mathrm{PM}_{2.5}$ was relatively even (one-way ANOVA, $p>0.5$ at a significance level of $95 \%$ ). The average concentrations of $\mathrm{Pb}$ were $365.2,463.9$, and $490.6 \mathrm{ng} \mathrm{m}^{-3}$ in $\mathrm{PM}_{10}$, and $310.9,265.1$, and $316.3 \mathrm{ng} \mathrm{m}^{-3}$ in $\mathrm{PM}_{2.5}$ at $\mathrm{BNU}, \mathrm{CS}$, and $\mathrm{YH}$, respectively, in the winter of 2002. The higher concentration of $\mathrm{Pb}$ at $\mathrm{YH}$ site could be ascribed to the coal combustion in heating season plus the industrial pollutants from the 
up-wind area of CS brought by the northwest wind. The average concentrations of $\mathrm{Pb}$ at the suburban site, MY, were $139.7 \mathrm{ng} \mathrm{m}^{-3}$ in TSP and $98.7 \mathrm{ng} \mathrm{m}^{-3}$ in $\mathrm{PM}_{2.5}$, respectively, both much lower than that at the traffic site, BNU, in autumn of 2003. In the spring of 2004, the $\mathrm{Pb}$ concentration in TSP was similar to that in autumn of 2003, while in $\mathrm{PM}_{2.5}$, $\mathrm{MY}$ even showed higher $\mathrm{Pb}$ concentration than that at BNU site. Dust storm in spring carries significant quantities of pollutants, which are from the mixing of mineral aerosol with pollution aerosol such as industrial soot, toxic metals and acidic gases on the transport pathway (Sun et al., 2004b). The high concentration of $\mathrm{Pb}$ in spring at suburban site indicated that large part of $\mathrm{Pb}$ in fine particles was likely from the long-range transported dust from outside Beijing.

The pollution level of $\mathrm{Pb}$ in Beijing was the heaviest among the five cities of China, i.e. Beijing, Shanghai, Qingdao, Duolun, and Yulin. The average concentrations of $\mathrm{Pb}$ in autumn of 2003 in Shanghai were 45.5 and $39.3 \mathrm{ng} \mathrm{m}^{-3}$ in TSP and $\mathrm{PM}_{2.5}$, respectively, nearly five times lower than those in Beijing. In the spring of 2004, TSP and $\mathrm{PM}_{2.5}$ samples were collected synchronously at the five cities, the concentration of $\mathrm{Pb}$ in Beijing was nearly twice higher than that in Shanghai. Although the usage of the leaded gasoline had been officially prohibited for 2 years in Shanghai, the automobile exhaust still contributed most of $\mathrm{Pb}$ pollution to the atmosphere in Shanghai (Wang et al., 2000). The number of motor vehicles rapidly increased and reached near to 1.7 million in 2004 in Shanghai, close to that in Beijing (2.2 million), which could have much heavier $\mathrm{Pb}$ pollution in Shanghai than other small cities. Even so, $\mathrm{Pb}$ concentration in Beijing was still higher than that in Shanghai. The pollution level of $\mathrm{Pb}$ in TSP in Qingdao was comparable with that in Shanghai (two sample $t$ test, $p=0.614$ at the 0.05 level), while the concentration of $161.4 \mathrm{ng} \mathrm{m}^{-3}$ of $\mathrm{Pb}$ in $\mathrm{PM}_{2.5}$ in Qingdao was close to that in Beijing $\left(175.7 \mathrm{ng} \mathrm{m}^{-3}\right)$, but nearly twice higher than that in Shanghai $\left(85.5 \mathrm{ng} \mathrm{m}^{-3}\right)$. Qingdao is a coastal city which, at the end of 2003, possessed over a million motor vehicles. In spring, dust storm mixing pollutants on the pathway passes through Qingdao, making the air pollution worse than other seasons. Thus the high concentration of $\mathrm{Pb}$ in Qingdao was likely from the local emissions plus the vehicle emissions in Northern China brought into Qingdao by dust storm (Guo et al., 2004). The concentration of $\mathrm{Pb}$ in
Duolun was $\sim 30 \mathrm{ng} \mathrm{m}^{-3}$ in both TSP and $\mathrm{PM}_{2.5}$. The concentration of $\mathrm{Pb}$ in Yulin was also less than $100 \mathrm{ng} \mathrm{m}^{-3}$. Duolun is located near the Hunshandake sand desert and Yulin near the Mu Us desert. Both the two sites showed much lower concentration of $\mathrm{Pb}$ compared with Beijing, as they have much fewer vehicles plus the clean air brought by westerly winds with cold fronts frequently passed through them.

\subsection{Temporal and seasonal variations of $\mathrm{Pb}$ in Beijing}

Fig. 2 shows the variations of $\mathrm{Pb}$ in TSP, $\mathrm{PM}_{10}$, and $\mathrm{PM}_{2.5}$ at $\mathrm{BNU}$ site from 2001 to 2004. Although the average concentrations of $\mathrm{Pb}$ in TSP, $\mathrm{PM}_{10}$, and $\mathrm{PM}_{2.5}$ were all below the National Ambient Air Quality Standard, a few peaks that exceeded the National standard, mostly concentrated in winter/ spring, were observed. For example, the highest concentrations of $\mathrm{Pb}$ reached 1446.5, 1534.3, and $1348.9 \mathrm{ng} \mathrm{m}^{-3}$ in $\mathrm{PM}_{2.5}, \mathrm{PM}_{10}$, and TSP, respectively, all higher than the annual average standard of $1000 \mathrm{ng} \mathrm{m}^{-3}$. The concentration of $\mathrm{Pb}$ showed significant daily variations in winter ranging from 9.8 to $813.1 \mathrm{ng} \mathrm{m}^{-3}$ in TSP in winter of 2001 , and 68.7-1534.3 $\mathrm{ng} \mathrm{m}^{-3}$ in $\mathrm{PM}_{10}$ and 44.6-1446.5 $\mathrm{ng} \mathrm{m}^{-3}$ in $\mathrm{PM}_{2.5}$ in the winter of 2002. Relatively minor temporal variation of $\mathrm{Pb}$ was observed in summer. As the temporal variations are largely determined by the strength of source emission, the significant variations of $\mathrm{Pb}$ in winter were likely due to more pollution sources in winter than other seasons. In addition, the meteorological conditions, such as temperature, relatively humidity, and wind speed, positively or adversely affect the dispersion of $\mathrm{Pb}$.

Seasonal variation of $\mathrm{Pb}$ is also exhibited in Fig. 2. The concentration of $\mathrm{Pb}$ showed the highest value in winter, $\sim 2-3$ times higher than that in summer. At BNU site, the concentration of $\mathrm{Pb}$ in $\mathrm{PM}_{2.5}$ was 206.0 and $310.9 \mathrm{ng} \mathrm{m}^{-3}$ in winter of 2001 and 2002 , respectively, $\sim 2-3$ times higher than $109.6 \mathrm{ng} \mathrm{m}^{-3}$ in the summer of 2002. The concentration of $\mathrm{Pb}$ in TSP reached 236.9, 303.4, and $307.9 \mathrm{ng} \mathrm{m}^{-3}$ in the spring of 2002, 2003, and 2004, all much higher than $93.6 \mathrm{ng} \mathrm{m}^{-3}$ in the summer of 2002 and $193.9 \mathrm{ng} \mathrm{m}^{-3}$ in the autumn of 2003. The higher concentrations of $\mathrm{Pb}$ in winter were likely from the much higher consumption of the domestic coal for heating and the vehicle exhausts in this season, as more coal is burned for the domestic heating in winter and the emission from the automobiles would produce 

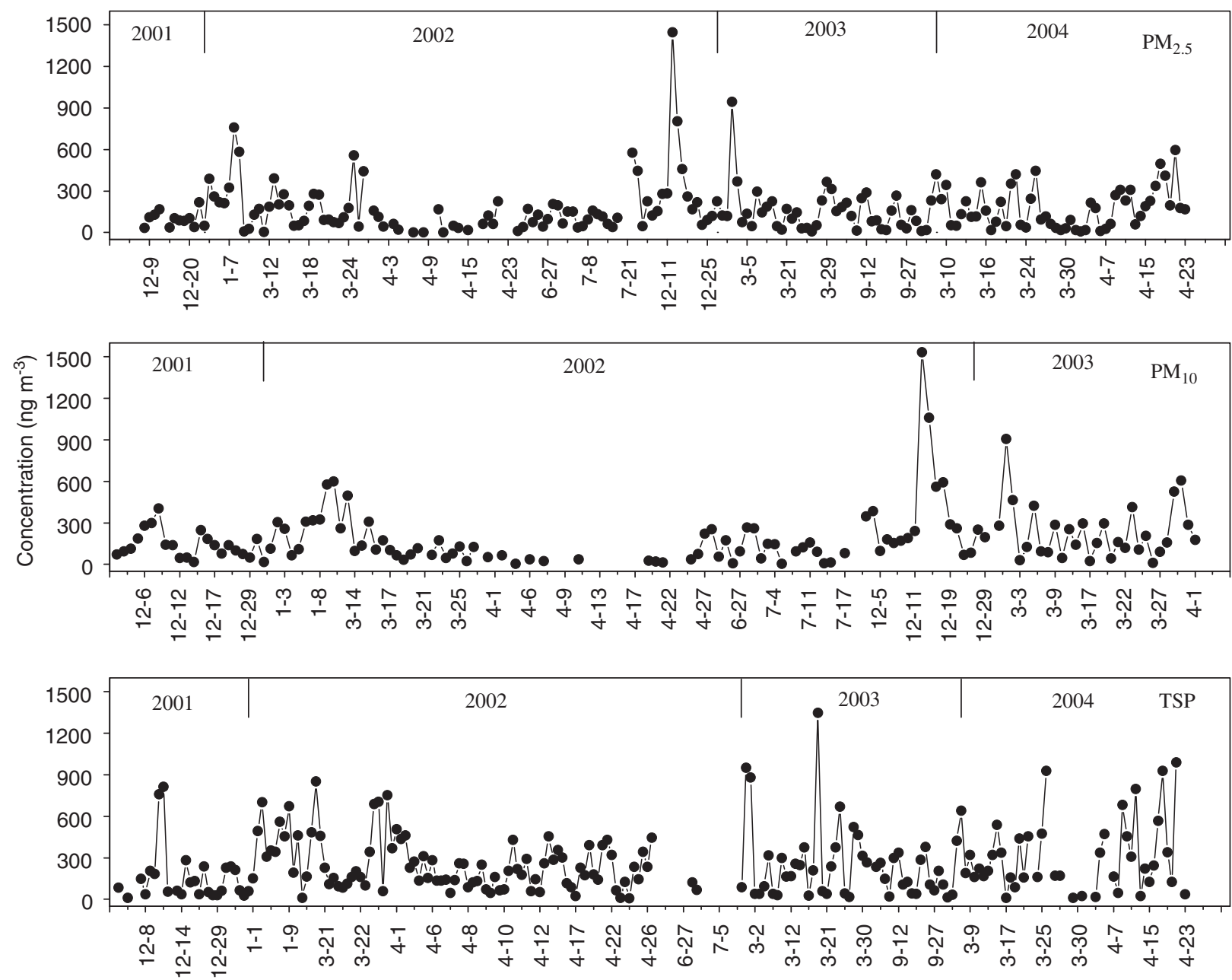

Fig. 2. Variations of $\mathrm{Pb}$ in TSP, $\mathrm{PM}_{10}$, and $\mathrm{PM}_{2.5}$ at $\mathrm{BNU}$ site from 2001 to 2004.

higher exhausts in the cold season due to the incomplete combustion of fuel running in colder weather (Simpson and Xu, 1994). The high concentrations of $\mathrm{Pb}$ in spring were likely due to coal combustion for heating in winter, plus the pollutants brought by dust storms, which affect Beijing frequently in spring. Meteorological conditions could also be the factors affecting the level of $\mathrm{Pb}$. The low wind speed and low temperature in winter favor accumulation of pollutants, while the high temperature in summer favors the air convection and the dispersion of pollutants. In addition, more road dust, in which $\mathrm{Pb}$ deposited previously, could be re-suspended in winter due to the barer surface, while pollutants would be more easily washed out because of the ample precipitation in summer Though the high wind speed in spring favors the dispersion of pollutants, it could also re-suspend more pollution dust, which enhances the concentration of particles in the atmosphere. Moreover, the higher wind speed would introduce more transported dust, which mixes with large amounts of pollutants, including $\mathrm{Pb}$, emitted on the pathway. Both these factors could increase the pollution level of $\mathrm{Pb}$ in Beijing.

\subsection{Size distribution of $\mathrm{Pb}$ in Beijing}

Knowledge of the size distribution is essential in understanding the sources of $\mathrm{Pb}$ and its effect on human health. Fig. 3 presents six sets of the size distribution of $\mathrm{Pb}$ from August 2000 to March 2001. The size distribution of $\mathrm{Pb}$ was mostly characterized by unimodal mode with the peak in the size range of 0.5-1 $\mu \mathrm{m}$ (29 September and 30 October, 2000). The unimodal size distribution of $\mathrm{Pb}$ with the peak in the 

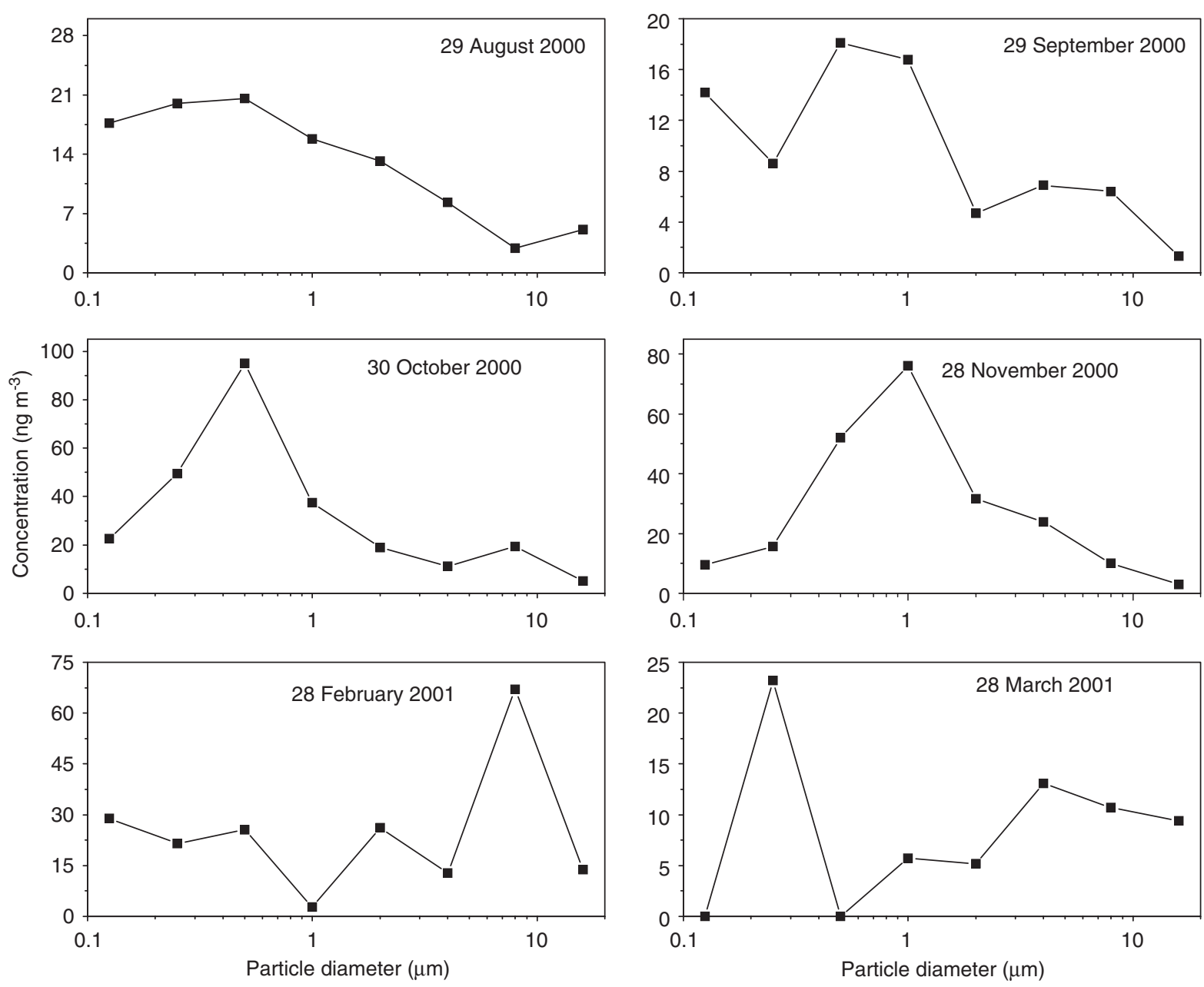

Fig. 3. Typical size distribution of $\mathrm{Pb}$ collected at the Institute of Atmospheric Physics, Chinese Academy of Science in Beijing from 2000 to 2001 .

range of 4-8 $\mu \mathrm{m}$ was also observed on 28 February, 2001. However, bimodal model of $\mathrm{Pb}$ was sometimes found (28 March, 2001). The size distributions of $\mathrm{Pb}$ showed great changes in different seasons. For instance, the major part of $\mathrm{Pb}$ shifted from fine fractions in winter to coarse fractions in spring. Different size distributions suggest different sources. $\mathrm{Pb}$ in fine fraction with size smaller than $2 \mu \mathrm{m}$ was usually from those anthropogenic sources, such as vehicle exhaust and coal combustion, while $\mathrm{Pb}$ in coarse fraction was from the natural sources, such as the re-suspension of road dust. Fig. 4 shows the variations of $\mathrm{Pb}$ concentration in fine particles $(>2 \mu \mathrm{m})$ and coarse particles $(>2 \mu \mathrm{m})$. The results indicated that most part of $\mathrm{Pb}$ in winter was

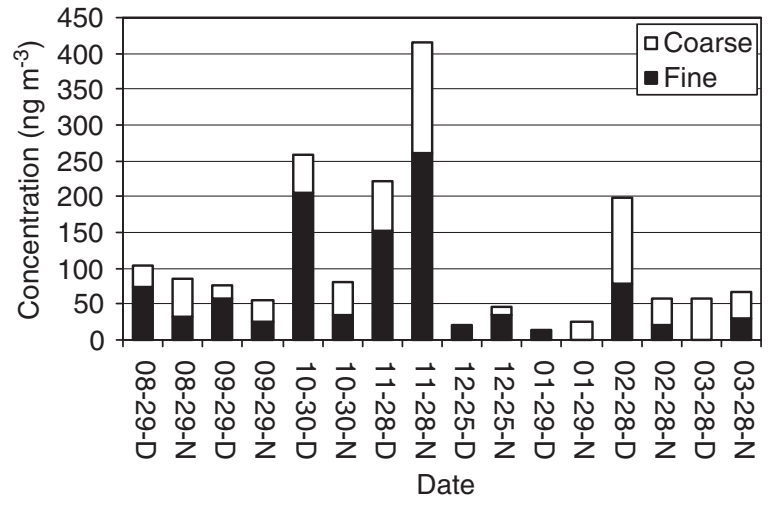

Fig. 4. Variations of $\mathrm{Pb}$ concentration in fine particles $(>2 \mu \mathrm{m})$ and coarse particles $(>2 \mu \mathrm{m})$ from 2000 to 2001 in Beijing (D: daytime; N: nighttime). 
concentrated in fine fractions contributing more than $\sim 60-80 \%$ of the total $\mathrm{Pb}$. $\mathrm{Pb}$ in coarse particles contributed more of the total than that in fine particles in spring, which was likely due to more transported dust in this season. The transported dust mixed large amounts of pollutants emitted from pollution sources on the pathway and then carried them to Beijing, which became one of the major sources of $\mathrm{Pb}$ in spring (Sun et al., 2005). The comparison of $\mathrm{Pb}$ concentrations between day and night is also shown in Fig. 4. Generally, the $\mathrm{Pb}$ concentration in fine particles in the daytime was higher than that at the nighttime, which would likely be due to more anthropogenic activities in the daytime, such as vehicle exhaust and industry emission, which could introduce more pollutants in fine particles than that at the nighttime.

\subsection{Sources of $\mathrm{Pb}$ in Beijing}

\subsubsection{Enrichment factor ( $E F$ ) of $P b$}

$\mathrm{EF}$ is usually used as the first step to evaluate the strength of pollution sources in relation with crustal sources (Gao et al., 1992). The EF for $\mathrm{Pb}$ is defined as

$\mathrm{EF}=(\mathrm{Pb} / \mathrm{Al})_{\text {sample }} /(\mathrm{Pb} / \mathrm{Al})_{\text {crust }}$,

where $\mathrm{Al}$ is selected as the reference element of crust. $(\mathrm{Pb} / \mathrm{Al})_{\text {aerosol }}$ is the concentration ratio of $\mathrm{Pb}$ to $\mathrm{Al}$ in the aerosol sample, and $(\mathrm{Pb} / \mathrm{Al})_{\text {crust }}$ is the average ratio of $\mathrm{Pb}$ to $\mathrm{Al}$ in crust (Taylor and McLennan, 1985). The EF of $\mathrm{Pb}$ was calculated and listed in Fig. 5. The results showed that the atmospheric concentration of $\mathrm{Pb}$ in $\mathrm{PM}_{2.5}$ in Beijing was $200-1600$ times higher than that in crustal soil. The high EF suggested that the dominant sources for $\mathrm{Pb}$ were noncrustal and a variety of pollutions emissions might contribute to its loading in the ambient air. Fig. 5 also illustrated the remarkably higher EF values of $\mathrm{Pb}$ in Beijing than other cities of China. For example, the element $\mathrm{Pb}$ in fine particles in Duolun and Yulin was enriched by a factor of only $27-46$ relative to its natural abundance in crustal soil. These results suggest that Beijing is in heavy $\mathrm{Pb}$ pollution area compared with Duolun and Yulin, which are near the desert regions that are less influenced by the anthropogenic sources.

In Beijing, $\mathrm{Pb}$ pollution was heavier in urban areas than in suburban site. In addition, the industrial site, $\mathrm{CS}$, and the residential site, $\mathrm{YH}$, located downwind of $\mathrm{CS}$, showed higher $\mathrm{EF}$ of $\mathrm{Pb}$ than that at traffic site $\mathrm{BNU}$, which suggested that industry emission was an important source of $\mathrm{Pb}$ in Beijing as mentioned above. Coal combustion was another significant factor for the high concentration of $\mathrm{Pb}$ in Beijing, as the higher $\mathrm{EF}$ of $\mathrm{Pb}$ was generally found in winter, when more coal was used for heating than other seasons. We also noted much higher $\mathrm{EF}$ of $\mathrm{Pb}$ in $\mathrm{PM}_{2.5}$ than those in $\mathrm{PM}_{10}$ and

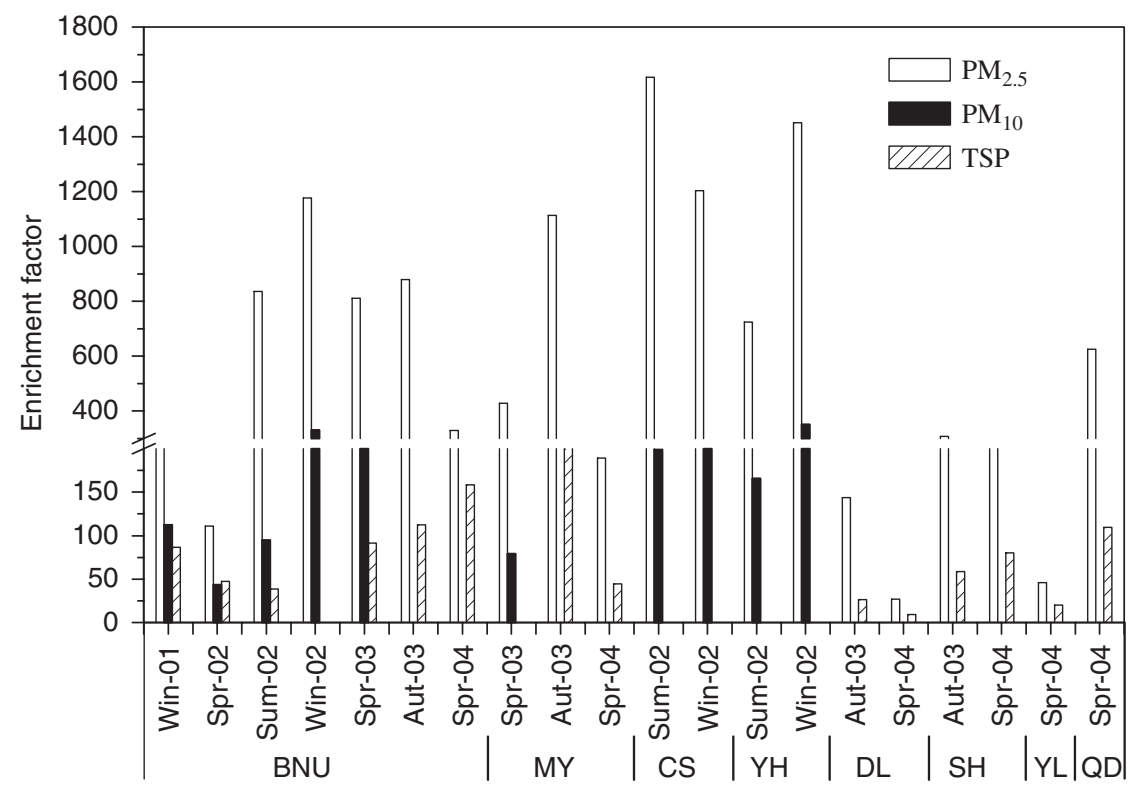

Fig. 5. Enrichment factor of $\mathrm{Pb}$ in different seasons from 2001 to 2004 at five cities of China (DL: Duolun; SH: Shanghai; YL: Yulin; QD: Qingdao). 
TSP, which indicated that the pollution element, $\mathrm{Pb}$, was more enriched in fine particles. Fine particles can enter the human body more easily than coarse particles and deposit in the tracheobronchial and alveolar regions of the lung, and $\mathrm{Pb}$ would be accumulated continuously and have more harmful effect on the human being.

Those soil particles contaminated could be resuspended in the atmosphere by wind and become an important source of pollution elements (Young et al., 2002). In Beijing, $\mathrm{Pb}$ was enriched by 1.9-33.3 times in soil particles $(<30 \mu \mathrm{m})$ compared with its natural crustal abundance, whereas the $\mathrm{EF}$ of $\mathrm{Pb}$ in those soil samples at Duolun in Inner Mongolia was close to unit (0.51-1.32), indicating that those soil in Duolun had hardly any $\mathrm{Pb}$ contamination. The high enrichment factor of $\mathrm{Pb}$ in Beijing soils was likely due to the input of the human activities, such as the deposition from previously emitted leaded-gasoline vehicle exhaust. Lankey et al. (1998) reported that over half of the total emitted lead is deposited on roads and those soils nearby. These particles would be re-suspended by vehicular movement/wind action and become one of major sources of $\mathrm{Pb}$ in the atmosphere.

\subsubsection{Factor analysis}

Factor analysis (FA, Varimax rotated principal component analysis) was performed with the elemental data sets of TSP, $\mathrm{PM}_{10}$, and $\mathrm{PM}_{2.5}$ respectively to further identify the possible sources of $\mathrm{Pb}$ in Beijing. To maximize the source-identification power, 12 species (the total mass, $\mathrm{As}, \mathrm{Zn}, \mathrm{Pb}$, $\mathrm{Ni}, \mathrm{Cd}, \mathrm{Fe}, \mathrm{Mn}, \mathrm{Ca}, \mathrm{Cu}, \mathrm{Al}$, and $\mathrm{S}$ ) were selected. Five factors for TSP, and four factors for $\mathrm{PM}_{10}$ and $\mathrm{PM}_{2.5}$, were resolved, as shown in Table 4. Five factors for TSP explained $93.4 \%$ of the total variance. The communities for all species were higher than 0.81 , indicating the five factors identified were satisfactory. Among the five factors, the second factor was related to the source of $\mathrm{Pb}$, which explained $20.0 \%$ of the variance. This factor showed high loadings for $\mathrm{Zn}, \mathrm{Pb}$, and $\mathrm{S}$, representing the combined sources of industry emission, vehicle exhaust, and coal burning. The industrial metallurgical processes could produce the largest emissions of $\mathrm{Zn}, \mathrm{Cu}, \mathrm{Ni}$, and $\mathrm{Pb}$, while exhaust emissions from road vehicles also contain variable quantities of $\mathrm{Zn}$, $\mathrm{Cu}$, and $\mathrm{Ni}$ (Pacyna, 1998). As leaded gasoline has been banned since 1997 in Beijing, the emission of those vehicles should not be the dominant source of $\mathrm{Pb}$ in Beijing aerosols. However, the illegal use of

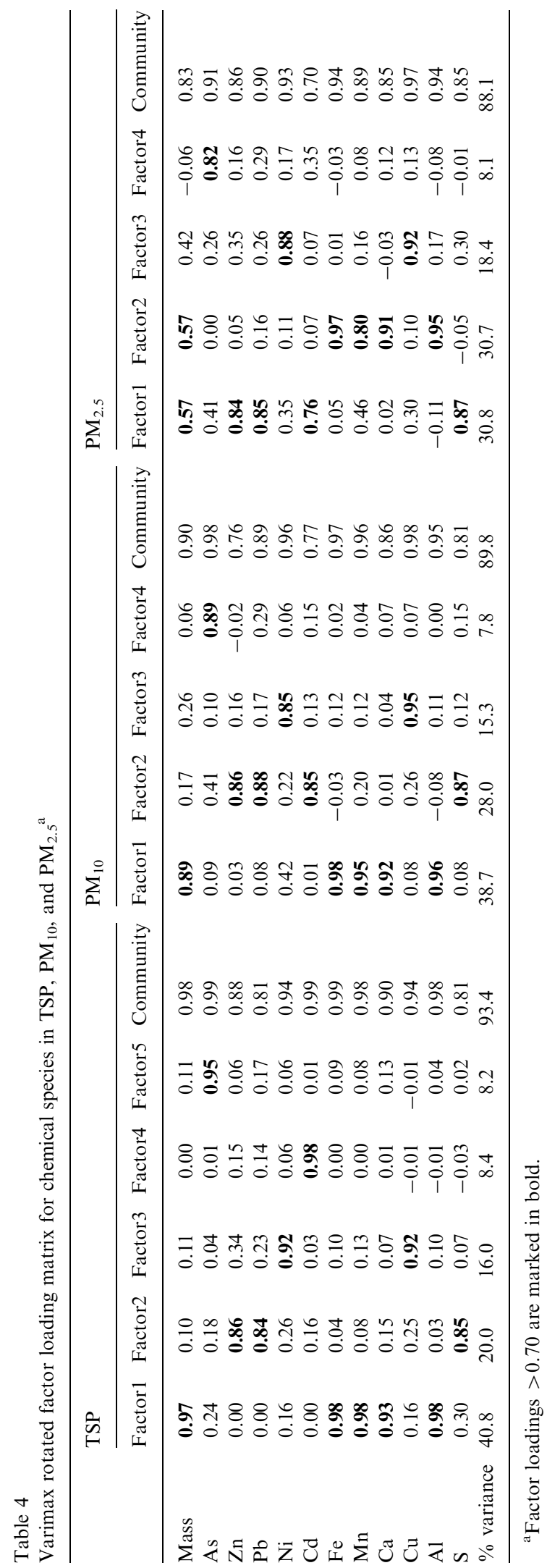


leaded gasoline in the vicinal provinces and cities surrounding Beijing was found, which produced $\mathrm{Pb}$ pollution that could be transported into Beijing. Also, vehicles using leaded gasoline often travel from other cities to Beijing, which further worsens the burden of $\mathrm{Pb}$ in Beijing aerosols. $\mathrm{Pb}$ was found to be abundant in those dusts collected in the paved road, which was likely due to the deposition of those previously emitted exhausts of the leaded-gasoline vehicle. $\mathrm{S}$ exists mainly as sulphate, particularly, in the forms of ammonium sulphate, ammonium bisulphate, and sulphuric acid (Sweet and Gatz, 1998). The abundance of sulphate was strongly correlated with $\mathrm{SO}_{2}$ in atmosphere that was mainly from the consumption of coal both in industry and in domestic families and, in turn, converted to sulphate through chemical transformation (Sun et al., 2004a). This factor with high loadings for $\mathrm{Zn}, \mathrm{Pb}$, and $\mathrm{S}$ indicated that vehicle exhaust, coal burning, and industry emission could be the multiple sources of $\mathrm{Pb}$.

Four factors were retained when applying FA to $\mathrm{PM}_{10}$ and $\mathrm{PM}_{2.5}$, which explained $89.8 \%$ and $88.1 \%$ of the variance, respectively. Among the four factors, the second factor in $\mathrm{PM}_{10}$ and the first factor in $\mathrm{PM}_{2.5}$ were related to $\mathrm{Pb}$, which were loaded with $\mathrm{Pb}, \mathrm{Zn}, \mathrm{Cd}$, and $\mathrm{S}$, indicating that industry emission, vehicle exhaust, and coal combustion were the combined sources of $\mathrm{Pb}$ pollution in the atmosphere in Beijing as discussed above for TSP.

\section{Conclusions}

A 5-year programme monitoring $\mathrm{Pb}$ was conducted at four sites in Beijing and the other four cities in China. $\mathrm{Pb}$ pollution in Beijing has been very serious when compared with other sites over the world, as the concentration of $\mathrm{Pb}$ in Beijing remained as high as $\sim 100-300 \mathrm{ng} \mathrm{m}^{-3}$ in fine particles $\left(\mathrm{PM}_{2.5}\right)$. Significant spatial variation of $\mathrm{Pb}$ in summer with the highest concentration at the industrial site was observed, while relatively even spatial variation was found in winter in urban area, although much heavier in the urban area than at suburban site. Strong seasonal variation of $\sim 2-3$ times higher $\mathrm{Pb}$ concentration in winter than that in summer was found. $\mathrm{Pb}$ exhibited a unimodal size distribution with most of it in fine fraction. $\mathrm{Pb}$ in fine particles was enriched by a factor of 200-1600 relative to its abundance in crust. Major contributions to the atmospheric loading of $\mathrm{Pb}$ could include industry emission, motor vehicle emission, coal burning, and long-range transported dust from outside Beijing. Re-suspended soil that contained the deposition from previously emitted leadedgasoline vehicle exhaust could be another important source of $\mathrm{Pb}$. This work could provide the basic information in reducing the pollution level of $\mathrm{Pb}$ in Beijing.

\section{Acknowledgements}

This work was funded by the Swedish International Development Cooperation Agency (SIDA) through the Asian Regional Research Program on Environmental Technology (ARRPET) at the Asian Institute of Technology and supported by the National Natural Science Foundation of China (Grant Nos. 30230310 20077004, 2047700, and 40575062) and Beijing Natural Science Fund (Grant Nos. 8991002 and 8041003), and also in part supported by LAPC, The Institute of Atmospheric Physics, CAS.

\section{References}

Centers for Disease Control and Prevention, 1991. Preventing lead poisoning in young children: a statement from the Centers for Disease Control and Prevention, Atlanta, 1991.

Chen, X., Teng, H., Wang, F., He, J., Zhou, S., Jian, Y., Xiao, X., 2003. Blood lead level and related risk factors among children aged $0-6$ years in Beijing. Chinese Journal of Epidemiology 24 (10), 868-871 (in Chinese).

Chen, Z., Ge, S., Zhang, J., 1994. Measurement and analysis for atmospheric aerosol particulates in Beijing. Research of Environmental Sciences 7 (3), 1-9 (in Chinese).

Chow, J.C., Waston, J.G., Lu, Z., Lowenthal, D.H., Frazier, C.A., Solomon, P.A., Thuiller, R.H., 1996. Descriptive analysis of $\mathrm{PM}_{2.5}$ and $\mathrm{PM}_{10}$ at regionally representative locations during SJVAQS/AUSPEX. Atmospheric Environment 30, 2079-2112.

Fang, G.C., Chang, C.N., Wu, Y.S., Fu, P.P.P., Yang, C.J., Chen, C.D., Chang, S.C., 2002. Ambient suspended particulate matters and related chemical species study in central Taiwan, Taichung during 1998-2001. Atmospheric Environment 36, 1921-1928.

Gao, Y., Arimoto, R., Duce, R.A., Lee, D.S., Zhou, M.Y., 1992. Input of atmospheric trace elements and mineral matter to the Yellow Sea during the spring of a low-dust year. Journal of Geophysical Research 97 (D4), 3767-3777.

Gao, Y., Nelson, E.D., Field, M.P., Ding, Q., Li, H., Sherrell, R.M., Gigliotti, C.L., Van Ry, D.A., Glenn, T.R., Eisenreich, S.J., 2002. Characterization of atmospheric trace elements on $\mathrm{PM}_{2.5}$ particulate matter over the New York-New Jersey harbor estuary. Atmospheric Environment 36, 1077-1086.

Guo, Z., Feng, J., Fang, M., Chen, H., Lau, K.H., 2004. The elemental and organic characteristics of $\mathrm{PM}_{2.5}$ in Asian dust 
episodes in Qingdao, China, 2002. Atmospheric Environment 38, 909-919.

Han, L., Zhuang, G., Sun, Y., Wang, Z., 2005. Local and nonlocal sources of airborne particulate pollution at Beijing - the ratio of $\mathrm{Mg} / \mathrm{Al}$ as an element tracer for estimating the contributions of mineral aerosols from outside Beijing. Science in China (Ser. B) 48 (4), 253-264.

He, K., Yang, F., Ma, Y., Zhang, Q., Yao, X., Chan, C.K., Cadle, S., Chan, T., Mulawa, P., 2001. The characteristics of $\mathrm{PM}_{2.5}$ in Beijing, China. Atmospheric Environment 35, 4959-4970.

Ho, K.F., Lee, S.C., Chan, C.K., Yu, J.C., Chow, J.C., Yao, X., 2003. Characterization of chemical species in $\mathbf{P M}_{2.5}$ and $\mathrm{PM}_{10}$ aerosols in Hong Kong. Atmospheric Environment 37, 31-39.

Hu, W., Wu, G.P., 1999. The lead pollution level in particulate of the four cities in China. Environmental Monitoring in China 15 (3), 5-7.

Kim, K.H., Choi, G.H., Kang, C.H., Lee, J.H., Kim, J.Y., Youn, Y.H., Lee, S.R., 2003. The chemical composition of fine and coarse particles in relation with the Asian dust events. Atmospheric Environment 37, 753-765.

Lankey, R.L., Davidson, C.I., McMichael, F.C., 1998. Mass balance for lead in the California south coast in air basin: an update. Environmental Research Section A 78, 86-93.

Miller, M.S., Friedlander, S.K., Hidy, G.M., 1972. A chemical element balance for the Pasadena aerosol. Journal of Colloid and Interface Science 39, 165-176.

Mishra, V.K., Kim, K.H., Kang, C.H., Choi, K.C., 2004. Winter time and distribution of airborne lead in Korea. Atmospheric Environment 38, 2653-2664.

Nriagu, J.O., 1979. Global inventory of natural and anthropogenic emissions of trace metals to the atmosphere. Nature 279, 409-411.

Nriagu, J.O., 1989. A global assessment of natural sources of atmospheric trace metals. Nature 338, 47-49.

Nriagu, J.O., Pacyna, J.M., 1988. Quantitative assessment of worldwide contamination of air, water and soils by trace metals. Nature 333, 134-139.

Pacyna, J.M., 1998. Source inventories for atmospheric trace metals. In: Harrison, R.M., Van Grieken, R. (Eds.), Atmospheric Particles, IUPAC Series on Analytical and Physical Chemistry of Environmental Systems, Vol. 5. Wiley, Chichester, UK, pp. 385-423.

Pakkanen, T.A., Loukkola, K., Korhonen, C.H., Aurela, M., Makela, T., Hillamo, R.E., Aarnio, P., Koskentalo, T., Kousa, A., Maenhaut, W., 2001. Sources and chemical compositions of atmospheric fine and coarse particles in the Helsinki area. Atmospheric Environment 35, 5381-5391.

Simpson, R.W., Xu, H., 1994. Atmospheric lead pollution in an urban area-Brisbane, Australia. Atmospheric Environment 28, 3073-3082.
Sun, Y., Zhuang, G., Wang, Y., Han, L., Dan, M., Guo, J., Zhang, W., Wang, Z., Hao, Z., 2004a. The air-borne particulate pollution in Beijing-concentration, composition, distribution and sources. Atmospheric Environment 38, 5991-6004.

Sun, Y., Zhuang, G., Yuan, H., Zhang, X., Guo, J., 2004b. Characteristics and sources of 2002 super dust storm in Beijing. Chinese Science Bulletin 49 (7), 698-705.

Sun, Y., Zhuang, G., Wang, Y., Zhao, X., Li, J., Wang, Z., An, Z., 2005. Chemical composition of dust storm in Beijing and implications for the mixing of mineral aerosol with pollution aerosol on the pathway. Journal of Geophysical ResearchAtmosphere, 110, D24209, doi:10.1029/2005JD006054.

Sweet, C.W., Gatz, D.F., 1998. Summary and analysis of available PM2.5 measurements in Illinois. Atmospheric Environment 32, 1129-1133.

Taylor, S.R., McLennan, S.M., 1985. The Continental Crust: Its Composition and Evolution. Blackwell, Oxford, England.

Wang, J., Guo, P., Li, X., Zhu, J., Reinert, T., Heitmann, J., Spemann, D., Vogt, J., Flagmeyer, R., Butz, T., 2000. Source identification of lead pollution in the atmosphere of Shanghai city by analyzing single aerosol particles (SAP). Environmental Science and Technology 34, 1900-1905.

Wang, W., Liu, X., Zhao, L., Guo, D., Lu, Y., 2003. Assessment of the phase-out of leaded gasoline in Tianjin, China using isotope technique. China Environmental Science 23 (6), 627-630 (in Chinese).

Winchester, J.W., Bi, M., 1984. Fine and coarse aerosol composition in an urban setting: a case study in Beijing, China. Atmospheric Environment 18, 1399-1409.

Wong, C.S.C., Li, X.D., 2004. Pb contamination and isotopic composition of urban soils in Hong Kong. The Science of the Total Environment 319, 185-195.

Ye, B., Ji, X., Yang, H., Yao, X., Chan, C.K., Cadle, S.H., Chan, T., Mulawa, P.A., 2003. Concentration and chemical composition of $\mathrm{PM}_{2.5}$ in Shanghai for a 1-year period. Atmospheric Environment 37, 499-510.

Young, T.M., Heeraman, D.A., Sirin, G., Ashbaugh, L.L., 2002. Re-suspension of soil as a source of airborne lead near industrial facilities and highways. Environmental Science and Technology 36, 2484-2490.

Zhang, R., Wang, M., Zhang, W., Wang, Y., Li, A., Zhu, G., 2000. Research on elemental concentrations and distributions of aerosol in winter/summer in Beijing. Climatic and Environmental Research 5 (1), 6-12 (in Chinese).

Zhuang, G., Guo, J., Yuan, H., Zhao, C., 2001. The compositions, sources, and size distribution of the dust storm from China in spring of 2000 and its impact on the global environment. China Science Bulletin 46 (11), 895-901.

Zhuang, G., Guo, J., Yuan, H., Zhang, X., 2003. Coupling and feedback between Iron and sulphur in air-sea exchange. China Science Bulletin 48 (11), 1080-1086. 